THE AUtHORS REPLY: Drs. Steiger and Turowski make an important point regarding the association between fibromuscular dysplasia and intracranial aneurysms, for which the prevalence has been reported to be as high as 51 percent.1,2 However, the prevalence estimates may be falsely elevated because of selection bias; many of the patients with aneurysms in these series underwent angiography after presenting with subarachnoid hemorrhage. Fibromuscular dysplasia was an incidental finding in some of the reported cases. ${ }^{3}$

When patients who presented with subarachnoid hemorrhage are excluded from the prevalence estimates, the prevalence of incidental, asymptomatic cerebral aneurysms in patients with internal-carotid-artery or vertebral-artery fibromuscular dysplasia is only 7.3 percent. ${ }^{3}$ By comparison, a meta-analysis of 23 studies (with a total of 56,304 patients) showed a prevalence of intracranial aneurysms of 0.4 percent in retrospective autopsy series, 3.6 percent in prospective autopsy series, 3.7 percent in retrospective angiography studies, and 6.0 percent in prospective angiography studies; the annual risk of rupture was 0.7 percent. ${ }^{4}$ Given the wide variation in prevalence reported in the literature, we recommend routine screening with magnetic resonance angiography in all patients with cerebrovascular fibromuscular dysplasia. ${ }^{5}$

David P. Slovut, M.D., Ph.D.

Jeffrey W. Olin, D.O.

Mount Sinai School of Medicine

New York, NY 10029

jeffrey.olin@msnyuhealth.org

1. Mettinger KL. Fibromuscular dysplasia and the brain. II. Current concept of the disease. Stroke 1982;13:53-8.

2. George B, Mourier KL, Gelbert F, Reizine D, Raggueneau JL. Vascular abnormalities in the neck associated with intracranial aneurysms. Neurosurgery 1989;24:499-508.

3. Cloft HJ, Kallmes DF, Kallmes MH, Goldstein JH, Jensen ME, Dion JE. Prevalence of cerebral aneurysms in patients with fibromuscular dysplasia: a reassessment. J Neurosurg 1998;88:436-40.

4. Rinkel GJ, Djibuti M, Algra A, van Gijn J. Prevalence and risk of rupture of intracranial aneurysms: a systematic review. Stroke 1998; 29:251-6.

5. Slovut DP, Olin JW. Fibromuscular dysplasia. N Engl J Med 2004;350:1862-71.

\title{
Case 15-2004: Cancer Therapy and Sperm Banking
}

TO THE EDITOR: With regard to Case 15-2004 (May 13 issue), ${ }^{1}$ I would like to add an important point to the discussion of the impact of cancer therapy on fertility. Although the authors correctly note the association between testicular irradiation and the impaired synthesis of testosterone, they do not comment on the greater threat to spermatogenesis posed by the high doses of testicular radiation (18 Gy) and cyclophosphamide that were used to treat this patient. Doses of radiation above 4 Gy lead to azoospermia in most men, ${ }^{2}$ and alkylating agents such as cyclophosphamide are a common cause of infertility. ${ }^{3}$ Because of this treatment toxicity, young men should be offered the opportunity to bank sperm before undergoing cancer therapy involving alkylating agents or testicular irradiation. ${ }^{4}$ This simple procedure can be overlooked in the busy initial stage of therapy; however, permanent infertility may result. Fortunately, banked sperm can subsequently be used in assisted reproductive techniques to achieve fertility with high rates of success.

John K. Amory, M.D.

University of Washington

Seattle, WA 98195

jamory@u.washington.edu

1. Case Records of the Massachusetts General Hospital (Case 152004). N Engl J Med 2004;350:2081-7.
2. Rowley MJ, Leach DR, Warner GA, Heller CG. Effect of graded doses of ionizing radiation on the human testis. Radiat Res 1974;59: 665-78.

3. Howell SJ, Shalet SM. Male hypogonadism resulting from cancer and cancer treatments. In: Winters SJ, ed. Male hypogonadism. Totowa, N.J.: Humana Press, 2004:247-62.

4. Anger AT, Gilbert BR, Goldstein M. Cryopreservation of sperm: indications, methods and results. J Urol 2003;170:1079-84.

THE AUTHORS REPLY: We appreciate the information provided by Dr. Amory. Infertility is a major concern after stem-cell transplantation.1,2 We agree that sperm banking should be offered before chemotherapy is started.

Fortunately, in this case, our patient did bank sperm before proceeding with chemotherapy. One year after undergoing allogeneic stem-cell transplantation, he continues to do well.

Karen K. Ballen, M.D.

Robert P. Hasserjian, M.D.

Massachusetts General Hospital

Boston, MA 02114

1. Chatterjee R, Kottaridis PD. Treatment of gonadal damage in recipients of allogeneic or autologous transplantation for hematological malignancies. Bone Marrow Transplant 2002;30:629-35.

2. Sanders JE, Hawley J, Levy W, et al. Pregnancies following highdose cyclophosphamide with or without high-dose busulfan or total-body irradiation and bone marrow transplantation. Blood 1996; $87: 3045-52$. 